\section{På tide å skifte spor}

Liv-Ellen Vangsnes har en viktig lederartikkel i Tidsskriftet nr. $3 / 2016$ der hun beskriver flere problematiske sider ved dagens sykehusdrift (1). I fortsettelsen av hennes bidrag er det naturlig å drøfte hvor alvorlig situasjonen kan bli om ikke pasientene og faget står sentralt for ledere i helsetjenesten. Et sykehus er ikke en produksjonsbedrift med mål om å selge varer i et marked. Helsetjenesten består av kunnskapstunge, problemløsende institusjoner. Velferdstjenestene er et spleiselag som skal sørge for at vi alle skal få den hjelpen vi trenger.

Filosofen Hans Skjervheim ville nok ha kalt ideologien bak sykehusreformen for et kategorimistak (2). Og den østerrikske filosofen Ludwig Wittgenstein ville ha minnet oss på at «språket forhekser forstanden», at de ordene vi bruker, skaper virkelighet. Produksjon (pasientbehandling), ordrereserve/biomasse (venteliste), levere varene (adekvat hjelp til pasienter i rett tid) er eksempler på slike ord.

Ekstra alvorlig kan det bli for driften av sykehus om helsepersonell trakasseres når de tar opp forhold som bør endres. I 2014 reiste jeg rundt i Norge for å intervjue allmennpraktikere og sykehusleger om hvordan de hadde opplevd trakasseringen fra overordnede. De hadde erfart alt fra munnkurv til trusler, skriftlige advarsler, usaklige oppsigelser, politianmeldelser og arbeidsrettssaker. Flere leger på sykehus er blitt erklært uønsket $i$ enhver stilling i helseregionen fordi de var «en fare for pasientene». Ingen av disse hadde en eneste klage på seg til tilsynsmyndighetene, verken fra pasienter, pårørende eller kolleger. Noen går heldigvis i ettertid med rak nakke og er i full jobb etter trakasseringen. Andre er uføretrygdet, noen har reist fra landet, mens enkelte har vært på randen av å ta sitt eget liv (3).

Må vi fortsette å finne oss i at helsevesenet styres i stedet for å ledes? Er det umulig å bli kvitt ideologien som ligger til grunn for kravet om lojalitet til de styrende i stedet for til faglig forsvarlig pasientbehandling? Nei. Vi kan se til Skottland. Der skrotet de sin foretaksmodell for mer enn ti år siden til fordel for en heloffentlig sykehustjeneste, rammefinansiert og uten innsatsstyrt finansiering. Og det går svært bra. I 2013 fikk en forskergruppe fra Norge møte helseministeriet, opposisjonens «helseminister» og alle de aktuelle fagforeningene for sykehusansatte. Alle var enige om at «butikkmodellen» var de ferdige med. Etter omleggingen til ren forvaltning har skottene erfart en betydelig nedgang bl.a. i dødeligheten i sykehus, sykehusinfeksjoner og sykmeldinger blant ansatte. I tillegg holdes budsjettene hvert år (4).

Helsepersonellet har fått tilbake glød, engasjement og stolthet, fikk vi høre. Nøkkelen til suksessen ligger nok i at helseministeriet leder gjennom tillit, ikke mistillit og konkurranse. Helseministeren uttalte at det er befolkningen og helsepersonellet som vet hva som skal til for å få en optimal helsetjeneste. Dette viste de i praksis ved å ha kontakt med alle landets helsestyrer hver måned. «Er vi på rett vei? Er det noe som bør endres?» spurte helseministeriet.

Norge må kvitte seg med foretaksmodellen for ikke å bli faglig akterutseilt, noe som igjen vil gå utover pasientene. Vi kan risikere å miste dyktig helsepersonell og få manglende rekruttering til helsevesenet om vi fortsetter i samme spor. Mens vi venter på å få snudd «tankskipet», kan vi skjele til det den administrerende direktøren på sykehuset på Hønefoss gjør. Per Skaugen Bleikelia praktiserer det han har skrevet på kontordøren: «Ansvarlig tilrettelegger for Ringerike sykehus» (5). Han har snudd hierarkipyramiden og plasserer seg selv nederst. Under et intervju i 2014 fortalte han meg at målet er at legene på sykehuset skal få bruke $90 \%$ av arbeidstiden sin på pasientrettet virksomhet. Hans «helter» er de som går i hvitt, «og disse må vi ta godt vare på» (3). Det er etter hans mening helsepersonellet som har den mest krevende jobben i et sykehus. Historiene er mange om hva tillit, respekt og samarbeid har gjort med trivsel og faglig fokus på Ringerike sykehus. «Det er første gang i mitt lange liv som sykehuslege at jeg har opplevd at en direktør kommer og spør meg om det er noe jeg mangler i jobben min», sa en kollega jeg møtte nylig.

Oppfordringen går egentlig til alle fagforeninger i offentlig sektor: Vi må kreve at vi forlater en modell for organisering og drift av velferdstjenestene som er blitt både dyrere og dårligere enn forutsatt da den såkalte «moderniseringen av offentlig sektor» ble innført. Stortinget må sørge for at de som politikere igjen får kunnskap om hva som foregår i helsetjenesten. Våre folkevalgte må ikke skyve ansvaret for utvikling og drift over på foretakene. I mellomtiden må vi som leger støtte kolleger som opplever trakassering fra overordnede når de sier ifra om forhold som er uheldige. Vi må ikke vike unna i frykt.

\section{Eli Berg}

el-be4@online.no

Eli Berg (f. 1947) er førsteamanuensis ved Universitetet i Oslo/campus Akershus universitetssykehus

\footnotetext{
Litteratur

. Vangsnes L-E. Det syke huset. Tidsskr Nor Legeforen 2016; 136: 203.

Skjervheim H. Deltakar og tilskodar og andre essays. Oslo: Aschehoug, 2001

Berg E. Hold munn eller gå! Makt og avmakt i helsevesenet. Oslo: Emilia, 2015.

4. Eilertsen R. Lerdommer fra Skottlands solidariske helsevesen. Oslo: For Vetferdsstaten/De Facto, 2013

5. Tveito M. En ansvarlig tilrettelegger. Tidsskr Nor Legeforen 2015; 135: 1446-8
}

Publisert først på nett 